\title{
Öğretim Programlarında Değerler: Hayat Bilgisi Dersi Örneği
}

\section{Values in Curricula: A Case of Life Science Course}

\author{
Cihat Yaşaroğlu ${ }^{\mathrm{a}, *}$ \\ ${ }^{a}$ Doç. Dr., Bingöl Üniversitesi, Fen Edebiyat Fakültesi, Psikoloji Bölümü, 12000, Bingöl/Türkiye. \\ ORCID: 0000-0002-9574-1789
}

\section{MAKALE BILLGISİ}

\section{Makale Geçmişi:}

Başvuru tarihi: 13 Şubat 2018

Düzeltme tarihi: 20 Mart 2018

Kabul tarihi: 27 Mart 2018

Anahtar Kelimeler:

Öğretim Programı

Değerler

Hayat Bilgisi

\section{ARTICLE INFO}

\section{Article history:}

Received 13 February 2018

Received in revised form 20 March 2018

Accepted 27 March 2018

\section{Keywords:}

Curriculum

Values

Life Science Course
ÖZ

İlkokulun ilk üç senesinde okutulmakta olan Hayat Bilgisi Dersinin temel amaçlarından birisinin olumlu kişilik özellikleri kazandırmak olduğu dikkate alındığında, dersin değerler eğitimi açısından önemi artmaktadır. Bu açıdan değerlendirildiğinde, öğretim programlarının değerlere ne ölçüde yer verdiğinin bilinmesi gerekmektedir. Bu çalışma, 1926'dan günümüze kadar hayat bilgisi derslerine ait programlarda değerlerin / değer ifadelerinin ne ölçüde yer aldığını belirlemek amacıyla yapılmıştır. Çalışmada nitel araştırma desenlerinden durum çalışması kullanılarak gerçekleştirilmiştir. Tüm hayat bilgisi programlarına matbu ya da Talim ve Terbiye Kurulu Başkanlığ web sitesinden ulaşılmıştır. Program ögeleri içerisinde değer ifadelerinin ne ölçüde yer aldığı incelenmiştir. Yapılan incelemeler sonucunda tüm programların belli ölçülerde değerler / değer ifadelerine yer verdiği, son üç program olan 2018, 2017 ve 2015 programlarında açıktan değer vurgularının yapıldı̆̆ı sonuçlarına ulaşılmıştır.

\section{A B S T R A C T}

Considering that one of the main objectives of the Life Science lesson which is being taught in the first three years of primary school is to acquire positive personality traits, the importance of this lesson is increasing. When assessed in this respect, it is necessary to know how much the curricula provide for the values. This study was conducted to determine the extent to which values / value expressions take place in the curricula of life science lessons from 1926 to the present day. The study was carried out using qualitative research and case study design was used. All life sciences curricula have been accessed printed or from the Board of Education web site. Whether or not the values are included in the program items and how it takes place are examined. As a result of the examinations, the results were achieved as the value expressions were made openly in the last three programs, 2018, 2017 and 2015, in which all programs included certain values.

\section{Giriş}

Bilim ve teknolojide yaşanan hızlı değişim, bireyin ve toplumun değişen ihtiyaçları, öğrenme öğretme teori ve yaklaşımlarındaki yenilik ve gelişmeler bireylerden beklenen rolleri de etkilemiştir. Bu değişim bilgiyi üreten, hayatta işlevsel olarak kullanabilen, problem çözebilen, eleştirel düşünen, girişimci, kararlı, iletişim becerilerine sahip, empati yapabilen, topluma ve kültüre katkı sağlayan niteliklerdeki bir bireyi tanımlamaktadır. Bu niteliklere sahip bireylerin yetiştirilmesi için öğretim programları salt bilgiden ziyade bireysel farklılıkları da dikkate alan, değer ve beceri kazandırmayı hedeflemelidir (MEB, 2018).
Duyuşsal gelişim eğitimi, bireyin gelişim sürecinde, duygusal gelişme sürecini etkileyen ya da etkilemeye çalışan bir müdahale olarak tanımlanmaktadır. $\mathrm{Bu}$ tanım en geniş anlamı ile formal ve informal eğitimi, okul ve aile eğitimini de içermektedir. Genelde duyuşsal öğrenmenin temel felsefesi çok açık ve net olup "bozulmamışsa yapılmaz" mantığına dayanır (UNESCO, 1992). Günümüzde artan bazı toplumsal ve bireysel problemler, eğitimde de duyuşsal alan öğrenmelerinin öne çıkmasına temel oluşturmaktadır. Değerler eğitiminin de duyuşsal öğrenme kapsamında ele alındığı düşünüldüğünde, bu durumun değerler eğitimi için de geçerli olduğu söylenebilir. Değer eğitimi, günümüz eğitim sistemleri ve eğitim anlayışı ve bilimsellik yaklaşımı

* Sorumlu yazar/Corresponding author.

e-posta: cyasaroglu@bingol.edu.tr 
içinde gerçekleştirilen veya önerilen uygulamalar olarak anlaşılmaktadır (Bacanlı, 2017).

Bir toplumun geleceğini, değerlerini benimsemiş, ve bu değerleri sahip olduğu yetkinliklerle gerçek hayatta gösteren insanlarına bağlıdır. Eğitim sistemlerinin, her bir üyesine uygun ahlaki kararlar alma ve bunları davranışlarında sergileme yeterliliğini kazandırması gerekmektedir. Programlar öğrencilere değerlerinin bütün yaşamlarında ne denli önemli olduğunu kavrayacak karakterin öğretilmesinde yardımcı olmaktadır. Neyin doğru ya da yanlış olduğuna dair kanaatlerin programda yer alması aynı zamanda değerlerin de yer aldığını göstermektedir. Programlar, öğrencilerin akademik olarak başarılı ve karakter açısından olumlu kişilik özelliklerine sahip iyi kişiler olmalarına ve bu şekilde de hem başarıya ulaşan hem de mutlu, kendilerini iyi hisseden, başkalarına nasıl davranmaları gerektiğini öğrenmelerine yardımcı olmayı amaçlamalıdır. Bu açıdan bakıldığında, akademik açıdan başarılı ve insani değerleri içselleştirmiş bireyler yetiştirmenin eğitimin en temel iki amacı olduğu söylenebilir. Temel değerleri benimsemiş bireyler yetiştirmek okulların asli görevidir; yeni neslin değerlerini, alışkanlıklarını ve davranışlarını etkileyebilmelidir. Okulun iki temel görevinden biri akademik ilerlemeyi esas alan bilişsel gelişim, diğeri ise karakter eğitimidir. Karakter eğitimi ile insani değerleri içselleştirmek anlaşılabilmektedir. Bu iki görev birlikte öğrencileri yaşama, yaşam boyu öğrenmeye ve vatandaşlığa hazırlamaktadır (Adeyemi vd., 2009; Ekşi, 2004; Flay ve Allred, 2010; MEB, 2018).

Eğitim programı öğrencilerin yaşamlarıyla alakalı olmalı ve onlara entelektüel, duygusal ve sosyal açıdan katkı sağlamalıdır. Öğrenciler sosyal ve duygusal olgunluk ve sağlam karar verme becerileri kazanır ki bu boyut daha sonra aktif yurttaşlığa kolayca dönüşebilen olumlu bir karakter özelliğidir. Etkili karakter eğitimi programları, akademik, bilișsel başarı için gerekli olan sorumlulukla da yüksek düzeyde ilişsilidir. Karakter eğitimi sonucunda kazanılan saygı ve sorumluluk, başarılı öğrenme deneyimleri açısından da temel teşkil etmekte olup karakter eğitimi akademik programların temel amaçlarından birisi olarak görülmelidir (Agboola ve Tsai, 2012; Flay ve Allred, 2010; Jacobs ve Jacobs-Spencer, 2001; Lickona, 2009). Program kültürün entelektüel ve ahlâki mirasını taşımalıdır. Ahlaki mirasın aktarımının gerçekleşmesi de programlar aracılığıyla olabilir (Lickona, 2004).

Öğrencilerin büyük bir çoğunluğu okullara devam ettiklerine göre, eğitim sistemi zorunlu olarak bir sosyalleşme aracı olmalı ve geleceğin toplumunu şekillendirmelidir. Örneğin eğitim programında değerlerin benimsenmesi, okul çağında olan tüm çocukların bazı değerleri kazanmalarını garanti altına almaktadır. Öğrencilerin, belirlenen vizyonu kazanabilmeleri için değerler ve tutumlar okul programlarının en temel ögelerinden biri olmalıdır. Ayrıca eğitim programı aynı zamanda kişinin gelişimini ve yaşam boyu öğrenmeyi teşvik edecek eğitim amaçlarına ulaşmak için öğrencilerin olumlu değer ve tutumlarını da geliştirmelidir (Curriculum Development Council, 2001; Powney vd., 1995).

Değerler eğitiminin şiddeti, saygısızlığı, eşitsizliği, ekolojik bozulmalar gibi sorunların azaltılmasında bir yol olduğuna inanılmaktadır. Ayrıca değerler eğitimi uygulamaları; öğrencilerde doğru ile yanlışı birbirinden ayırabilecek duygu, düşüncelerin kazandırılmasında öğretmenlere yardımcı olabilmektedir. $\mathrm{Bu}$ yüzden de değerler ile akademik ders planları birbirinden ayrı tutulmamalı, ders planları her zaman hem akademik hem de karakter ile ilgili kazanımlar içermelidir (Jacobs ve Jacobs-Spencer, 2001). Okullardaki karakter eğitiminin eksikliğinin en temel sebeplerinden biri de bazı dersler için hazırlanan planlarda öğretim içerikleri ile değerler eğitiminin birbirlerinden ayrı tutulmasıdır. Dolayısıyla değerlerin entegre edilmediği öğretim programlarının başarılı olması beklenemez (Lewis vd., 2011).

"Entegrasyona karşı ayrım” bu yaklaşımda duyuşsal alan öğrenmelerinin nasıl özelleştirileceği ile ilgilidir. Öğretim programı tablolarında duyuşsal alan için yer ayrılıp ayrılmadığına bağlıdır. Değerler eğitiminin diğer bir yolu da, bu alan için için özel bir ders ya da ders grubu tayin etmektir. Bu meyanda, "sosyal bilgiler" duyuşsal alan ile ilgili olan toplum eksenli mesajların iletilmesi için iyi bir aracıdır (UNESCO, 1992). Bireysel ve toplumsal değerlerin kazandırılması için Hayat Bilgisi dersi de aynı bağlamda değerlendirilebilir.

Bazı programlarda değerler açık bir şekilde yer alırken, bazılarında ise örtük bir şekilde yer almaktadır. Değerlerin açıktan yer aldığı bir program, duyuşsal alan için etkili bir program sayılır. Rusya, Çin, Malezya gibi bazı ülkelerde değerler, programların zorunlu bir parçası olarak programlarda yer almaktadır. Türkiye'de ise 2005 programlarına kadar değerler örtük bir şekilde yer alırken 2005 yılından sonra artık açıktan yer almaya başlamıştır (Bacanl1, 1999; Lovat vd., 2011; Yaşaroğlu, 2013). Okulda değerler doğrudan ya da dolaylı olarak öğretilebilmektedir. $\mathrm{Bu}$ durum okuldaki programların yapısını ve öğretim türlerini de etkileyebilmektedir. Değerler eğitiminin başarıya ulaşabilmesi olumlu kişiler arası ilişkiler ve nitelikli değeryüklü (value-laden) programlar aracılığıyla sağlanabilir. $\mathrm{Bu}$ programlar öğrenciler arasında olumlu ilişkileri artırırken okullarda sayg1, empati vb. değerleri içerikleriyle öğrencilere kazandırır (DeNobile ve Hogan, 2014; Lickona, 1996; Lovat vd., 2011; Yaşaroğlu, 2015b). Ancak ister örtük, ister açık olsun, gençlerin eğitimi için kullanılan programlar, öğrenciler için önemli olan unsurlar üzerine kurulu olup sistematik bir şekilde kazandırılmalıdır. Bu programlar aynı zamanda çevrelerindeki dünyaları gözlemlemeleri ve anlamalarına rehberlik etmeli ve aynı zamanda hem kendilerine hem de başkalarına saygılı olmayı öğretmelidir (Burton, 1998).

Öğretim programlarında değerlerin ne ölçüde yer aldığı ile ilgili literatür incelendiğinde, belli dönemler ya da belli programlar ile ilgili çalışmaların olduğu görülmektedir. İlköğretimde okutulmakta olan tüm derslere ait öğretim programlarında (Güven, 2013; Keskin, 2012; Yaşaroğlu, 2015a); Din Kültürü ve Ahlak Bilgisi programlarında (Çekin, 2012; Kaymakcan ve Meydan, 2011); Sosyal Bilgiler dersi öğretim programlarında (Balcı ve Yelken, 2013; Gömleksiz ve Cüro, 2011); Hayat bilgisi dersi programında değerler ile ilgili (Bahçe, 2010; Demir ve Demirhan İşcan, 2007; Kabapınar, 2007; Keskin ve Keskin, 2009; Narin, 2007; Orhan, 2013; Öztürk, 2009; Şimşek, 2013; Uzunkol, 2014; Yaşaroğlu, 2013a, 2015b) çalışmaları görülmektedir. Ancak Cumhuriyetten günümüze kadar hayat bilgisi dersi öğretim programlarının tamamını kapsayacak şekilde bir çalışmaya rastlanmamıştır. 
Bu çalışma, 1926 İlk Mekteplerin Müfredat Programı'ndan günümüze kadar Hayat Bilgisi Dersi programlarında değerlerin ne ölçüde yer aldığını ortaya koymak amacıyla yapılmıştır. Bu çalışmadan elde edilen verilerin, değerler eğitimi alanında çalışan araştırmacılara, lisansüstü eğitim alan öğrencilere, politika geliştiricilere faydalı olması umulmaktadir.

Cumhuriyetten günümüze kadar hayat bilgisi müfredatlarında/öğretim programlarında değerler ne ölçüde yer almıştır? Bu ana problem cümlesi ile beraber;

1926 İlk Mekteplerin Müfredat Programı,

1936 İlk Okul Programı,

1948 İlk Okul Programı,

1968 İlkokul Programı,

1998 İlkokul Programı

2005 Hayat Bilgisi Dersi Öğretim Programı (HBDÖP),

2015 HBDÖP,

2017 HBDÖP

2018 HBDÖP'ında değerler ne ölçüde yer almaktadır?

\section{Yöntem}

$\mathrm{Bu}$ araştırmada, Cumhuriyetten günümüze kadarki hayat bilgisi dersi programlarında değerlerin ne ölçüde yer aldığını belirlemek amacıyla yapılmıştır. Bu amaçla nitel araştırma yöntemlerinden olan "durum çalışması deseni" kullanılmıştır. Veriler, doküman analizi tekniği kullanılarak elde edilmiştir. "Nitel araştırma, gözlem, görüşme ve doküman analizi gibi nitel veri toplama yöntemlerinin kullanıldığı, algıların ve olayların doğal ortamda, gerçekçi ve bütüncül bir biçimde ortaya konmasına yönelik nitel bir sürecin izlendiği araştırma" olarak tanımlanabilir. Durum çalışması deseninde, çalışmaya konu olan ortam veya olayların bütüncül bir yorumu hedeflenmektedir. Aynı zamanda durum çalışması deseni, birden fazla kanıt veya veri kaynağının mevcut olduğu durumlarda kullanılmaktadır (Yıldırım ve Şimşek, 2016). Bu çalışmada birden fazla öğretim programının incelenmesi hedeflendiğinden dolayı durum çalışması deseni kullanılmıştır. Döküman incelemesi veya analizi tek başına bir araştırma yöntemi olabildiği gibi diğer nitel yöntemlerin kullanıldığı durumlarda ek bilgi kaynağı olarak ta kullanılabilir. Bu çalışmada nitel araştırma yöntemlerinden "doküman incelemesi tekniği”", tek başına bir veri toplama yöntemi olarak kullanılmıştır.

\subsection{Veri Toplama Kaynakları}

Hayat bilgisi dersine ait 1926, 1936, 1948, 1968, 1998, 2005, 2015, 2017 ve 2018 öğretim programları bu çalışmanın veri kaynaklarını oluşturmaktadır. Bu çalışmanın dokümanları, 2018 HBDÖP ile önceki hayat bilgisi dersi öğretim programlarından oluşmaktadır. 2018, 2017, 2015 ve 2005/2009 programlarına Talim ve Terbiye Kurulu Başkanlığı'nin (TTKB) resmi Web sayfasından ulaşılmıştır. Diğer programlara ise matbu olarak ulaşılmıştır. 1926 İlk Mekteplerin Müfredat Programı ile 1998 programlarına yine TTKB'den ulaşılarak fotoğrafları çekilmiş ve incelenmiştir. 1936 programına 1937 Son Kânun basımı Kültür Bakanlığı Dergisinin 20 Sayılı cildinden matbu olarak ulaşılmıştır.
1948 ve 1968 programları ise Milli Eğitim Baskısı olan matbu kitaplar edinilerek incelenmiştir.

\subsection{Verilerin Analizi}

Elde edilen veriler içerik analizine tabi tutulmuştur. İçerik analizinde elde edilen veriler önce kavramsallaştırılır, daha sonra bu kavramlara göre mantıklı bir biçimde düzenlenir ve yorumlanır. (Yıldırım ve Şimşek, 2011). Tüm programlar birer analiz birimi kabul edilerek araştırmacı tarafından içerik analizine tabi tutulmuştur. Çalışmanın güvenirliği açısından sıklıkla doğrudan alıntılara yer verilmiştir.

Son olarak sonuç başlığında 1926'dan 2018'e kadarki programların alt başlıklarında değerlerin nasıl yer aldığı tablo halinde gösterilmiştir. İncelenen içerikte değer ifadesi varsa "V", değer ifadesi yoksa "Y", programda değerler ile ilgili başlık yoksa " $B$ ", ilgili alt başlık değerlendirilmemişse inceleme dişı bırakılmış ve "ID" şeklinde sembolleştirilmiştir.

\section{Bulgular}

\subsection{6 İlk Mekteplerin Müfredat Programında Hayat Bilgisi ve Değerler}

1926 İlk Mekteplerin Müfredat Programında Hayat Bilgisi, "Dersin Mahiyeti, Dersin Hedefi, Hayat Bilgisi Dersinde Dikkat Edilmesi Gereken Hususlar ve müfredat" başlıklarından oluşmaktadır (Maarif Vekâleti, 1926). Dersin mahiyeti başlı̆̆ ilgili açıklamalar yer almaktadır.

İkinci başlıkta "Dersin Hedefleri” dokuz adet olarak belirtilmektedir. 5 numaralı hedef olan "Mektep hayatında, aile veya şehir muhitindeki insanlar arasında tahaddüs eden (meydana gelen) hakiki vakıalar münakaşa edilmek veyahut hayali masallar ve hikâyeler nakletmek suretiyle çocuklara ahlaki telkinler yapmak." değerler eğitimi ile ilgili bir amaç cümlesidir. Burada gerçek ve kurgusal olan olaylar üzerinden, öğrencilere ahlaklı olmanın telkin yoluyla öğretilmesi hedeflenmektedir. Yine dokuzuncu hedefte de "Müşterek mesai sayesinde talebe arasında teavün (yardımlaşma) ve tesanüt (dayanışma) hislerini uyandırmak ve kuvvetlendirmek" (Maarif Vekâleti, 1926) de hedeflenmektedir. $\mathrm{Bu}$ hedefte de öğrencilerin ortak yapabilecekleri etkinlikler aracılığıyla kendi aralarında yardımlaşma ve dayanışma değerlerinin geliştirilmesi amaçlanmaktadır.

Dersin işlenmesi için dikkat edilmesi gereken noktalar da programda belirtilmiştir. $\mathrm{Bu}$ açıklamalar incelendiğinde, değerler ile bağlantısı kurulabilecek bir açıklama yer almamaktadır. Müfredat (konu listeleri) incelendiğinde, sadece konu başlıklarından içerikte neler işlendiği/işleneceği anlaşılamayacağı için, konu başlıklarından değerler ile ilgili bir inceleme yapılmamış, dolayısıyla içerikte değerlerin ne ölçüde yer aldığı ile ilgili bulguya rastlanılmamıştır.

Genel olarak 1926 programında ahlaki değerlerin kazandırılması gerektiği vurgulandığı ve yine hedeflerde yardımlaşma ve dayanışma değerlerine vurgu yapıldığ ancak dersin işlenişinde uyulması gereken kurallar belirtilirken değerler ile ilgili ifadelerin ya da açıklamaların yer almadığı görülmektedir. 


\subsection{6 İlk Okul Programında Hayat Bilgisi ve Değerler}

1936 programında her dersin hedefi, ilgili bölümün başında yer almıştır. Hayat bilgisi dersinin d bendinde (Türe, 2013)

"Tabiatın güzelliklerini duyurmak ve sevdirmek" ile doğa sevgisi kazandırılmak amaçlanmaktadır. Hayat bilgisi dersinin e bendi ise daha çok milli değerleri kazandırmayı amaçlamaktadır. Dolayısıyla 1936 hayat bilgisi programının hedeflerinde sadece bu iki değerin vurgulandığ görülmektedir.

Ayrıca yine 1936 programında da konular sadece liste halinde verildiği (Kültür Bakanlığı, 1937) için değerler ile ilgili bir inceleme yapılmamıştır.

\subsection{Hayat Bilgisi Programında Değerler}

1948 Programında hayat bilgisi dersinin tanıtımı, amaçları, açıklamalar ve konu listeleri yer almaktadır (MEB, 1948). Hayat bilgisi dersinin kısa bir tanıtımının yapıldığı giriş k1sminda değerlerden herhangi bir şekilde bahsedilmemektedir. Dersin iki amacı belirtilmiştir. Birinci amacın dört alt amaçtan ilk ikisi değerler ile ilgilidir. Örneğin a bendinde “.... Tabiat güzelliklerine karşı sevgi ve tabiat öğelerinin korunması için iyi alışkanlıklar kazandırmak." (MEB, 1948: 40) çevresel değerler ile ilgili bir amaç cümlesidir. Diğer alt amaçta ise "Öğrencilerin evde okulda ve çevredeki insanlarla münasebetlerinde sevgi, saygı, doğruluk, işbirliği ve sorumluluk duygularını geliştirmek suretiyle onlarda yurda ve millete bağlılı̆̆ın temelini kurmak" amaçlanmaktadır (MEB, 1948: 40). Bu ifadelerde "sevgi, sayg1, doğruluk, işbirliği ve sorumluluk" değerleri doğrudan yer almaktadır.

Açıklamalar kısmında değerlerin işlenişi veya vurgulanması ile ilgili bir bilgi yer almamaktadır.

1948 programında konu listeleri bulunmaktadır. Hayat Bilgisi konuları sıralanmış, her bir konunun sonuna ise "Eğitsel sonuçlar" paragrafi eklenmiştir. Her üç sınıfın konularına bakıldığında, çeşitli değer ifadelerinin eğitsel sonuçlar paragraflarında yer aldığı görülmektedir. Program ile ilgili açıklamalarda, eğitsel konuların doğrudan öğrencilere nasihat şeklinde söylenmemesi, konular işlendikçe ve firsatlar doğdukça işlenmesi gerektiği (MEB, 1948: 44) önerilmektedir.

Eğitsel sonuçlarda bazı öneriler, doğrudan değer ifadeleri ile ilgilidir. 1. sinıf "Okulda" konusunun sonunda yer alan "Arkadaşlarımıza daima yardıma hazır olalım..... Bulduğumuz eşyanın sahibini arıyalım” (MEB, 1948: 49) eğitsel sonuçları dürüstlük ve yardımlaşma bağlamında değerlendirilebilir. "Evde Kış Eğlenceleri” konusunun "Evin büyüklerine saygı gösterelim. Küçüklerimizi hoş görelim." eğitsel sonucunda da görüleceği gibi saygı ve hoşgörü değerlerinin öğrenciye kazandırılması istenmektedir. 1. Sınıf konularından sadece eğitsel sonuçlar içerisinde değerler ile ilgili vurguların olduğu görülmektedir. Çevre temizliği, yardımlaşma, saygı, sevgi, doğruluk değerleri ön plana çıkmaktadır.

\subsection{8 İlkokul Programında Hayat Bilgisi ve Değerler}

1968 İlkokul Programında Hayat Bilgisi dersinin amaçları, açıklamalar ve üniteler halinde konular yer almaktadır. Dersin beş amacı belirlenmiştir. Dört alt amacı barındıran iki numaralı amaç, toplumsal ilişkiler yönünden öğrencilerin kazanmaları gereken değerleri ifade etmektedir. $\mathrm{Bu}$ alt amaçlarda sevgi, saygı, doğruluk, dayanışma, işbirliği, sorumluluk değerleri açıkça belirtilmektedir. Dördüncü alt amaç “...toplumun istediği davranışları göstermeye başlamak.” (MEB, 1968) ile toplumsal değerlerin kazanılmasının önemi amaç cümlesi olarak belirtilmiştir. Amaçların ardından "Açıklamalar" yer almaktadır. 17 açıklamadan hiçbiri değerler ile ilgili değildir.

Üniteler halinde konu listeleri verilmiştir. Bu programda öncekilerden farklı olarak, kimi konu başlıkları yanında parantez içerisinde olacak şekilde değer ifadeleri açıkça yer almaktadır. Konu isimlerine ve parantez içerisindeki açıklamalardan hareketle konuların değerler ile ilgili olup olmadığına karar verilebilir. 1. Sınıf "Evimiz ve Ailemiz" (3. Ünite) ünitesinde yer alan "Ailede bulunanların karşılıklı ilişkileri. (sevgi, saygı, yardımlaşma, vb.)" "Komşularımızla yardımlaşma” (MEB, 1968: 46) konuları sevgi, saygı, yardımlaşma değerleri ile ilişkilidir. Yine aynı şekilde ikinci sınıfın ilk ünitesinde yer alan "Okul Düzeni” konusunda “...öğretmenlere saygıllı olma ve arkadaşlarla iyi geçinme" (MEB, 1968: 49) değerler ile ilişkilendirilebilirken, üçüncü sınıf konuları içinde değerler ile ilişkili konu başlığı yer almamaktadır.

\subsection{Hayat Bilgisi Programında Değerler}

1998 programında (MEB, 2002) önceki programlardan farklı olarak, hedef ve davranışlar yer almaktadır. Hayat Bilgisi Programı, "Programın Uygulanmasıyla İlgili Esaslar" ile başlamaktadır. Bu esaslar incelendiğinde, değerler ile ilgili herhangi bir ifadenin yer almadığ 1 görülmektedir. Programda ayrıca ilk defa Hayat Bilgisi Dersinin Genel Hedefleri belirtilmiştir. $\mathrm{Bu}$ genel hedeflerden "3. Türk Milletinin kültürel değerlerini benimseyiş", " 5 . İnsanlara sevgi ve saygı duyuş", "7. Dayanışma ve işbirliği içinde olmayı alışkanlık haline getiriş" (MEB, 2002: 127) ve "20. Sorumluluğunu yerine getirme" (MEB, 2002: 128) hedefleri kültürel değerlere sahip çıkma, sevgi, saygı, sorumluluk, dayanışma, işbirliği değerleri ile ilişkilidir. Ayrıca genel hedeflerden hemen sonra yer alan özel hedeflerden ise "5. Insanlara sevgi ve saygı duyuş" ile "11. hak ve sorumluluklarını yerine getirebilme" (MEB, 2002: 128) de yine değerler ile ilgilidir.

1998 programında konular, "Ünite Planları” başlığı altında her sınıf için ayrı ayrı verilmiştir. Önce hedefler, altında ise hedefleri gerçekleştirebilecek davranışlar listelenmiştir. 1. sınıfın 2. ünitesindeki Hedef IV "Öğretmenine ve arkadaşlarına sevgi ve saygı duyuş" değerleri kazandırabilecek bir hedeftir. Hedef davranışların altında verilen konu listelerinde de "Sevgi, Saygı", "Hoşgörü, Dayanışma" (MEB, 1998: 135) konu başlıkları, doğrudan değer ifadeleri ile belirtilmiştir. Benzer şekilde "Ben ve Ailem" ünitesindeki bazı hedefler ve konu başlıkları değerlerle ilgilidir. Konu başlıklarında yer alan "Ailede İlişkiler" başlığı altında "1. Sevgi, Saygı, Hoşgörü”, "2. Sorumluluk, İş Bölümü” ile “3. Dayanışma” (MEB, 1998: 143) konuları aracılığıyla değerler eğitimi gerçekleştirlebilir. 


\subsection{HBDÖP ve Değerler}

2005/2009 HBDÖP'ında değerler ile ilgili müstakil bir başlık yer almamaktadır. Değerler "Programın Temel Yapısı ve Yaklaşımı" başlığı altında "Kişisel Nitelikler" ve "beceriler" alt başlıkları ile "Kazanımlar" başlıkları altında dağınık bir şekilde yer aldığı görülmektedir (MEB, 2009; Yaşaroğlu, 2013).

\subsection{HBDÖP ve Değerler ${ }^{1}$}

2015 HBDÖP, TTKB'nin 29.07.2015 tarih ve 60 sayll kararı ile 2016-2017 eğitim-öğretim yılından itibaren 1 . sınıflardan başlamak üzere kademeli olarak okutulmaya başlanmıştır (TTKB, 2018). Hayat Bilgisi Dersi Öğretim Programının Amaçları, Hayat Bilgisi Dersi Öğretim Programı Beceri ve Değerleri, Hayat Bilgisi Dersi Öğretim Programının Organizasyon Yapıs1, Hayat Bilgisi Dersi Öğretim Programının Ölçme Değerlendirme Anlayış1, Hayat Bilgisi Dersi Öğretim Programının Uygulanmasına İlişkin Açıklamalar ile her üç sınıf için ayrı olmak üzere "Öğretim Programı” başlıkları yer almaktadır (MEB, 2015).

Değerler ile ilgili amaçlar, "Hayat Bilgisi Dersi Öğretim Programı'nın Amaçları” başlığı altında yer almaktadır. Bu amaçlar şunlardır (MEB, 2015: 1):

2. Grupla çalışma, akranlarıyla iş birliği yapma ve sosyal katılım becerilerini geliştirmesi

4. Aileye ve aile içi ilişkilere dair bir anlayış geliştirerek aile ile ilgili temel değerleri içselleştirmesi

\section{Millî, manevi ve insani değerleri içselleştirmesi}

13. Doğayı ve çevreyi temiz tutma ve koruma becerilerini geliştirmesi

Amaçlardan da anlaşılacağı gibi, program değerlerin kazandırılmasını amaçlamaktadır. Bu değerler daha çok toplumsal değerler olarak değerlendirilebilir.

Programda ayrıca "Hayat Bilgisi Dersi Öğretim Programı Beceri ve Değerleri” başlığı yer almaktadır. Bu başlık altında 20 değer yer almaktadır. $\mathrm{Bu}$ değerler Tablo.1'de gösterilmiştir.

Tablo 1. 2015 Hayat Bilgisi Dersi (1-3. Sınıflar) Öğretim Programında Yer Alan Değerler

\begin{tabular}{llll}
\hline Adalet & Bilimsellik & Çalışkanlık & Dayanı̧̧ma \\
Doğa Sevgisi & Doğruluk & Dürüstlük & Estetik \\
Güven & Hoşgörü & Merhamet & Misafirperverlik \\
Öz Güven & Paylaşma & Sabır & Saygı \\
Sevgi & Sorumluluk & Vatanseverlik & Yardımlaşma \\
\hline Kaynak: MEB & $(2015)$ & &
\end{tabular}

Kaynak: MEB (2015)

HBDÖP'de "Ölçme ve Değerlendirme Anlayışı" başlığı altında öğretmenlere ölçme ve değerlendirme ile ilgili bilgiler verilmiştir. $\mathrm{Bu}$ açıklamalarda değerlerin değerlendirilmesi gerektiği "Öğrencilerin bilgi, beceri, tutum ve değerleri ne düzeyde kazandıkları; sınıf içinde yapılacak çeşitli etkinliklerde gösterdiği performans gözlemlenerek değerlendirilir.” (MEB, 2015: 3) şeklinde ifade edilmektedir.

Bir başka başlık ise programın uygulanmasına ilişkin açıklamalar kısmıdır. Programın uygulanmasında öğretmene rehberlik edecek açıklamalar bu başlık altında verilmiştir. İkinci açıklamada "öğretmenler; öğrencilerin bilişsel, duyuşsal ve devinişsel gelişimleri ile bireysel farklılıklarını dikkate almalıdır." denilmektedir (s. 4). Burada geçen duyuşsal gelişim değerleri de kapsadığı için, açıklamalar kısmında değerlerin yer aldığı söylenebilir.

Üç sınıfın öğretim programı farklı başlıklar altında ele alınmıştır. Sistematik olarak önce ilgili sınıfta işlenmesi gereken konular ile ilgili açıklamalar yer almaktadır. Sonrasında ünite adı, kazanım sayısı, ders saati ve ders saati yüzdeleri tablo halinde gösterilmektedir. Son olarak ise kazanımlara geçilmektedir. Değerler bağlamında incelendiğinde, konuların kısaca açıklandığı giriş paragraflarında, konular siralandiktan sonra, bu konularda öğrencilerin "bilgi, beceri ve tutum sahibi olmaları beklenmektedir" (MEB, 2015: 5) açıklaması yer almaktadır. $\mathrm{Bu}$ açıklamalarda değer vurgusunun yapılmadığı görülmektedir.

Her ünitenin başlangıcında bir açıklama paragrafı yer almakta ve bu paragraflarda öğrencilere çeşitli konularda "bilgi, beceri ve değer" kazandırmak amaçlanmaktadır. Her ünitenin altında sıralanan kazanımlarda ve açıklamalarda ise değer vurgusu yapılmakta ya da değerler ile ilişkilendirilebilecek ibareler yer almaktadır.

"1.1.9 Bayrak töreninde nasıl davranması gerektiğini kavrar." kazanımının açıklamasında "Türk bayrağına ve İstiklal Marşı'na saygı gösterme üzerinde durulacaktır." denilerek saygı değerine atıfta bulunulmaktadır.

Kazanımların gerçekleşmesinin "çalışkanlık" ve "sorumluluk" değerleri ile yakından ilişkili olduğu dikkate alındığında kazanımların en fazla ilgili olduğu değerlerin bu üç değer (özgüven, çalışkanlık, sorumluluk) olduğu söylenebilir. Her üç sınıfta da bulunan "Ülkemi Seviyorum" ünitesinde yer alan kazanımlar genel anlamda "vatanseverlik"; "Güvenli Hayat” ünitesindeki kazanımların daha çok öğrencilerin "güven"; "Doğa ve Çevre” ünitesinin "doğa sevgisi”; değerlerini kazandıracağı söylenebilir. Zira ünitenin pek çok kazanımında öğrencilere ilgili değerleri kazandıracak nitelikte kazanımlar olduğu söylenebilir. $\mathrm{Bu}$ durumda "çalışkanlık, sorumluluk, öz güven, güven, vatanseverlik, doğa sevgisi” değerlerinin programın genelinde en çok ilişkilendirilecek değerler olduğu söylenebilir.

"2.1.6. Sınıf ve okul içi çalışmalarda arkadaşlarıyla yardımlaşır." kazanımı "Konu; sevgi, saygı, hoşgörü, paylaşma, adil davranma, dürüstlük ve güven çerçevesinde ele alınacaktır.” (MEB, 2015: 12) şeklinde açıklanmaktadır. Bu kazanımda pek çok değer vurgulanmışken, bu değerlerin nasıl kazandırılacağı konusunda açıklayıcı bilgi verilmemiştir.

Parayı bilinçli bir şekilde harcama, tasarruf ile ilgili bir kazanım olmasına rağmen, tasarruf değerinin programın öngördüğü değerler arasında olmadığı görülmektedir.

Programda yer verilen değerler arasında olan "bilimsellik, estetik, misafirperverlik, sabır" değerleri ile herhangi bir kazanımın eşleşmediği görülmektedir.

\subsection{HBDÖP ve Değerler}

17.07.2017 tarih ve 72 sayılı TTKB kararı ile kabul edilen 2017 HBDÖP, toplamda 29 sayfadan oluşmaktadır (TTKB, 2018). Öğretim programının temel felsefesi açıklanırken, 
eğitim "bireyin içerisinde doğduğu milli, manevi ve kültürel değerler başta olmak üzere, yetenek, becer, tutum ve estetik duyarlık kazanılmasını içeren bir süreç" olarak tanımlanmaktadır. Ayrıca, öğrencilerin müreffeh bir toplumu oluşturan mutlu bireyler olmaları için "iyi", "doğru" ve "güzel" kavramlarının önemi ifade edilmiştir. Yine felsefi temeller başlığı altında sorumluluk sahibi olma, başkalarının duygularını anlama, grup etkinliklerinde yer alma, cömertlik, yardımseverlik, başkalarıyla iletişimde bulunma, müzakere etme, sorun çözme vb. gibi sosyal becerilere sahip milli değerlerle evrensel değerleri içselleştiren bireyler yetiştirilmesi gerektiği vurgulanmıştır (MEB, 2017: 3).

İkinci başlık olan "Öğretim Programının Genel Amaçları"ında, Hayat Bilgisi Dersi Öğretim Programının temel olarak ilkokul çağındaki öğrencilere birey, toplum ve doğa ekseninde temel bilgi, beceri ve değerleri kazandırmanın hedeflendiği belirtilmiştir. Bununla beraber, bireylerin sahip olması gereken hedefler belirtilirken, yine değerlerle ilgili cümle/ibarelere rastlanmaktadır. Örneğin "Aile ve toplumun temel değerlerine sahip olur." "Ülkesini sever, tarihî ve kültürel değerlerini yasatmaya istekli olur." ile "Millî, manevi ve insani değerleri yasatışla hâle getirir." amaçlarında değerler açıkça ifade edilmişken "Doğaya ve çevreye karşı duyarlı olur." amacında ise doğaya saygı değeri belirtilmektedir (MEB, 2017: 5).

Öğretim programı, “Temel Beceriler” (MEB, 2017: 5-6) ile devam etmektedir. $\mathrm{Bu}$ başlık altında da yine kültürel değerlere vurgu yapılmaktadır. Temel eğitimin temel amacının "milli, manevi, evrensel değerlere sahip, saygılı, mutlu..." bireyler yetiştirmek olduğu ifade edilmekte ve bu cümlelerde de değerler açık bir şekilde yer almaktadır. Türkiye Yeterlilikler Çerçevesinde (TYÇ), Avrupa Yeterlilikler Çerçevesi (AYÇ) ile uyumlu olacak şekilde tasarlanan becerilerden "sosyal ve vatandaşlıkla ilgili yeterlik" ile "kültürel farkındalık ve ifade" becerileri yine değerlerle ilişkilendirilebilir.

İlk defa 2017 programında “Öğretim Programı'nda Değerler Eğitimi” başlığı yer almaktadır. Bu açıdan bakıldığında, değerler eğitiminin tanımı, günümüz demokratik toplumlarında akademik başarı kadar bir takım değerlerin de önemli olduğu, bu değerleri benimseyen bireylerin birey ve toplum açısından önemi üzerinde durulmaktadır. Özellikle yine bu programda vurgulanan bir diğer husus ise öğretmenlerin değerler eğitimindeki öneminin vurgulanmasıdır. Ayrıca yine öğretmenlerin rol model olmalarının iyiyi ve doğruyu modelleme açısından önemi ifade edilmiştir. Bütün bunlarla beraber programda adalet, aile birliğine önem verme, bağımsızlık, bilimsellik, çalışkanlık, dayanışma, duyarlılık (doğal çevreye duyarlılık, kültürel mirasa duyarlılık), doğruluk, dostluk, dürüstlük, estetik, güven, merhamet, misafirperverlik, paylaşma, sabır, sayg1, sevgi, sorumluluk, vatanseverlik, vefa, yardımseverlik" değer ifadelerine yer verilmiştir (MEB, 2017: 8).

Yine ölçme değerlendirme ile ilgili açıklamalar kısmında öğrencilere kazandırılması planlanan bilgi, beceri ve değerler doğrultusunda uygun ölçme değerlendirme faaliyetlerinin yürütülmesi gerektiği belirtilmiştir (MEB, 2017: 8). Bir diğer başlık altında ise öğretim programının uygulanmasında dikkat edilecek hususlar belirtilmiştir. 10 . açıklamada programın uygulanmasında öğrencilerin değerleri kazanmasına özen gösterilmesi, tüm kazanımların ilgili değerlerle eşleştirilmesi ve örtük program anlayışından hareketle dersler islenmesi gerektiği ifade edilmiştir (MEB, 2017: 11).

\subsection{HBDÖP ve Değerler}

19.01.2018 tarih ve 13 sayılı TTKB kararı ile 2018 HBDÖP kabul edilmiş, 2018-2019 eğitim ve öğretim yılından itibaren tüm sınıf düzeylerinde uygulanmasına karar verilmiştir (TTKB, 2018). Bu programda, önceki iki programdan farklı olarak "Milli Eğitim Bakanlığı Öğretim Programları" başlığı eklenmiştir. Bu başlık altında öğretim programlarının "salt bilgi aktaran bir yapıdan ziyade bireysel farklılıkları dikkate alan, değer ve beceri kazandırma hedefi" olan bir program olduğu belirtilmektedir (MEB, 2018: 2). “Öğretim Programlarının Amaçları" kısmında yer alan 2 numaralı açıklama, "İlkokulu tamamlayan öğrencilerin gelişim düzeyine ve kendi bireyselliğine uygun olarak ahlaki bütünlük ve öz farkındalık çerçevesinde, öz güven ve öz disipline sahip, gündelik hayatta ihtiyaç, duyacağı temel düzeyde sözel, sayısal ve bilimsel akıl yürütme ile sosyal becerileri ve estetik duyarlılığı kazanmış, bunları etkin bir şekilde kullanarak sağlıklı hayat yönelimli bireyler olmalarını sağlamak" şeklindedir (MEB, 2018: 3). Bu açıklamadan da yine değer ifadeleri anlaşılmaktadır.

Öğretim Programlarının Perspektifi” başlı̆̆ı altında "Değerlerimiz" alt başlığı yer almaktadır. Burada "değerlerimiz toplumumuzun millî ve manevi kaynaklarından damıtılarak dünden bugüne ulaşmış, ve yarınlarımıza aktaracağımız öz mirasımız" olarak tanımlanmıştır. Ayrıca yetkinlikler "bu mirasın hayata ve insanlık ailesine katılmasını ve katkı vermesini sağlayan eylemsel bütünlükler" olarak tanımlanmış, değer - yetkinlik arasındaki ilişki açık bir şekilde ifade edilmiştir. "Değerlerimiz" alt başlığı altında, değerlerin öğretim programlarının perspektifini oluşturan ilkeler toplamı olarak ifade edilmektedir. Değerlerimiz, günlük hayatta karşılaşılan problemlerin çözülmesi için önemli bir güç kaynağı olarak belirtilmektedir. Ayrıca, yine eğitim sistemlerinin asli görevinin temel değerleri benimsemiş insanlar yetiştirmek olduğu net ifadelerle belirtilmiştir. Bu programda ilk defa kök değerler ifadesi kullanılmış ve kök değerler "adalet, dostluk, dürüstlük, öz denetim, sabır, sayg1, sevgi, sorumluluk, vatanseverlik, yardımseverlik" olarak tanımlanmıştır (MEB, 2018: 4).

2018 programının ölçme ve değerlendirme yaklaşımında, bireylerin ölçme ve değerlendirmeye konu olan ilgi, tutum, değer gibi özelliklerin zamanla değiştiği için, bu tür özelliklerin tek bir zamanda ölçülmesi yerine süreç içindeki değişimlerinin de ölçülmesi gerektiği vurgulanmaktadır (MEB, 2018: 6).

Yetkinlikler, temel beceriler, genel amaçlar ve uygulamada dikkat edilecek hususlar gibi başlıklar 2017 programında yer aldığ şekli iledir. Ancak 2018 programının temel becerileri içerisinden sorumluluk becerisi çıkarılarak beceri sayısı 23'e düşürülmüştür.

\subsection{Değerlerin Tüm Programlarda Yer Alma Durumlarına İlişkin Karşılaştırma}

1926 yılından 2018 yılına kadar geliştirilmiş olan programlarda değerlerin ne şekilde yer aldığı Tablo 2'de karşılaştırmalı olarak belirtilmiştir. Tabloda kısaca belirtilen 
hususlar bir sonraki başlık altında tartışılmıștır. ("V", değer ifadesi var; "Y" değer ifadesi yok; "B" ilgili başlık yok, "ID" ilgili alt başlık değerlendirilmemiştir).

Tablo 2. Hayat Bilgisi Programlarında Değerlere İlişkin Karşılaştırma

\section{Programın alt başlıkları

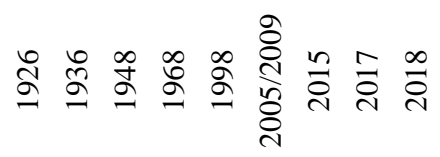

\begin{tabular}{|c|c|c|c|c|c|c|c|c|c|}
\hline $\begin{array}{l}\text { Dersin Mahiyeti/Giriş/Temel } \\
\text { yap1 ve yaklaşım/Felsefi temel }\end{array}$ & Y & B & $\mathrm{Y}$ & B & B & V & & & V \\
\hline Hedef/Amaç /Genel hedef & V & V & V & V & V & B & $\mathrm{V}$ & V & $\mathrm{V}$ \\
\hline Dersin İşlenmesinde Dikkat & & & & & & & & & \\
\hline $\begin{array}{l}\text { Edilecek } \\
\text { Hususlar/Açıklamalar }\end{array}$ & Y & B & Y & $\mathrm{Y}$ & $\mathrm{Y}$ & B & $\mathrm{V}$ & V & V \\
\hline $\begin{array}{l}\text { Ders listesi sonundaki eğitsel } \\
\text { sonuçlar }\end{array}$ & B & B & V & B & B & B & B & B & B \\
\hline Konular/Üniteler/Kazanımlar & İD & İD & İD & V & B & V & V & V & V \\
\hline Müstakil Değerler Başlığ & $\mathrm{Y}$ & $\mathrm{Y}$ & $\mathrm{Y}$ & $\mathrm{Y}$ & Y & $\mathrm{Y}$ & $\mathrm{V}$ & $\mathrm{V}$ & V \\
\hline $\begin{array}{l}\text { Temel Beceriler/Kişisel } \\
\text { Nitelikler }\end{array}$ & Y & Y & $\mathrm{Y}$ & $\mathrm{Y}$ & $\mathrm{Y}$ & $\mathrm{V}$ & $\mathrm{V}$ & $\mathrm{V}$ & $\mathrm{V}$ \\
\hline $\begin{array}{l}\text { Ölçme değerlendirme } \\
\text { yaklaşımı }\end{array}$ & Y & Y & Y & $Y$ & $\mathrm{Y}$ & $\mathrm{Y}$ & V & $\mathrm{V}$ & V \\
\hline
\end{tabular}

\section{Sonuç ve Değerlendirme}

1926 yılından 2018 yılına kadar geliştirilmiş olan programlarda değerlerin ne şekilde yer aldığı Tablo 2'de karşılaştırmalı olarak belirtilmiştir. Tabloda kısaca belirtilen hususlar tartışılmıştır. ("V", değer ifadesi var; "Y" değer ifadesi yok; ilgili başlık yoksa "B", ilgili alt başlık değerlendirilmemişse "İD” inceleme dişı).

1924 İlk Mekteplerin Müfredat programında müstakil "Hayat Bilgisi" dersi yokken, 1926 İlk Mekteplerin Müfredat Programından günümüze, hayat bilgisi dersi ilkokulun ilk üç sınıfında okutulmaktadır.

İlk olarak 1926 programında "Dersin Mahiyeti”, 1948 programında giriş kısmı, 2005 programında "Programın Temel Yapısı ve Yaklaşımı", 2018 programında "Öğretim Programının Temel Felsefesi" dersin genel bir tanıtımı ve son olarak 2018 programında Milli Eğitim Bakanlığ Öğretim Programları yer almaktadır. 1968 ve 1998 programında ise benzer başlık yer almamaktadır. 2005 programında değer ifadeleri Programın Temel Yapısı ve Başlığı altında yer alırken, 2017 ve 2018 programlarında çok daha açık bir şekilde değer vurgusu yapılmaktadır. 1926, 1948 ve 2015 programının giriş kısmında değerler ile ilgili ifadeler yer almamaktadır. Tüm programlar incelendiğinde 2005 yılı ve sonrasında geliştirilen programlarda giriş kısımlarında değer vurgusunun gittikçe arttığ1 görülmektedir. Bu da değerlere ve değerler eğitimine verilen önemin bir göstergesi olarak değerlendirilebilir. Çünkü bu başlık aynı zamanda programın dayandığı temel yaklaşımı da göstermektedir.

Programların incelenen ikinci başlığı olan "Hedef/Amaç/Genel Amaçları"nda ise tüm programlarda değer ifadelerinin olduğu görülmektedir. Ancak 2005 programında böyle bir başlık olmadığı için, bu program için aynı şeyler söylenemez. Program bazında incelendiğinde 1926 programında "yardımlaşma, dayanışma"; 1936 programında çevresel ve milli değerler; 1948 programında "çevreye sayg1, sevgi, sayg1, doğruluk, ișbirliği ve sorumluluk"; 1968 programında "sevgi, sayg1, doğruluk, dayanışma, işbirliği, sorumluluk"; 1998 programında "kültürel değerlere saygı, sevgi, saygı, dayanışma, işbirliği"; 2015, 2017 ve 2018 programında "milli, manevi, insani değerler, çevresel değerler, işbirliği”" değerlerine vurgu yapılmıştır. Son geliştirilen üç programda değerler için daha genel ifadeler kullanılmışken, önceki programlarda doğrudan değer ifadeleri yer almaktadır. Ancak pek çok programda da çevresel değerler ile işbirliği değerleri yer almaktadır. $\mathrm{Bu}$ bulgu, hayat bilgisi programlarında vurgulanan ana değerlerden birisinin de çevresel değerler olduğunu göstermektedir. Ayrıca iş birliği değerinin de yine toplumsal bir değer olarak tüm programlarda yer aldığı söylenebilir. 2005 programları üzerinden bir inceleme yapan Keskin (2012) ise ilköğretim programlarında "sevgi, sayg1, adil olma, barış, hoşgörü, yardımseverlik, vatanseverlik ve dürüstlük" değerlerinin tüm programlarda ortak değerler olarak yer aldığını belirtmişlerdir.

1936 ve 2005 programları hariç, incelenen programlarda üçüncü alt başlık olarak "Dersin İşlenmesinde Dikkat Edilecek Hususlar/Açıklamalar" yer almaktadır. Bu başlık altında programın işlenişi ile ilgili açıklamalar yer almaktadır. 2005 öncesi programların bu başlığı altındaki açıklamalarda değerler ile ilişkili ifadeler ya da değer vurgusu bulunmamaktadır. 2015 programında genel anlamda duyuşsal farklılıkların dikkate alınması gerektiği ifade edilirken, 2017 ve 2018 programlarının 10 . açıklamasında değerlerin kazandırılmasına özen gösterilmesi, kazanımlarla eşleştirilerek ilişkilendirilmesi ve örtük program anlayışıyla değerlerin kazandırılmaya çalışılması gerektiği açıklanmıştır. Bu değişim, her ne kadar 2005 programından sonra değerler doğrudan programlarda yer almaya başlamışsa da yine de örtük bir şekilde, ders içi ve ders dişı etkinliklerle de desteklenmesi gerektiğinin vurgulandığı şeklinde ifade edilebilir.

Sadece 1948 programında konu listelerinin sonunda eğitsel sonuçlar paragrafı eklenmiş ve bu paragraflarda da her dersin işlenişinde öğretmenlerin dikkat etmeleri gereken hususlar ifade edilmiştir. Bu paragraflarda da değer ifadelerinin yer aldığı görülmektedir.

1950'lere kadar olan program anlayışı daha çok konuların listeler halinde sunulması şeklindedir. 1926, 1936 ve 1948 programlarının sadece konu başlıklarına bakılarak değerler belirlenemeyeceği için bu programlar, inceleme dışı tutulmuştur. 1968 programında içerik, üniteler hâlinde belirtilmiştir. Bu programın içeriğine baktığımızda sevgi, sayg1, yardımlaşma değerlerinin olduğu görülmektedir. 1998 programında da üniteler olmakla beraber, ilk defa hedef davranışlar yer almaktadır. Yine bu hedef davranışlarda sevgi, saygı, hoşgörü, dayanışma, sorumluluk, işbirliği değerlerinin işlendiği görülmektedir. 2005, 2015, 2017 ve 2018 programlarında ise kazanımlar yer almakta ve kazanımlarda ise değer ifadeleri yer almaktadır.

Programlarda değerler ile ilgili olan başka bir başlıkta "Temel Beceriler" ya da "Kișisel Nitelikler" başlığıdır. Bu başlık altında yer alan ifadelerin bir kısmı doğrudan değer olarak da ele alınabilir. Hatta 2005 programında değerler kişisel nitelikler başlığı altında yer almaktadır. 2005 programına kadar bu tür başlı̆̆ın olmaması, değerlere verilen önem açısından yorumlanacak olunursa, değer kazandırmanın daha çok öğretmen insiyatifine bırakıldığı 
söylenebilir. 2005 programı ile beraber artık değerler de programlarda yer almaya başlamış ancak hala daha müstakil değer başlığına yer verilmemiştir. Bu durum da değerlerin öneminin anlaşıldığı, programlarda yer alması gerektiğinin kararlaştırıldığı ancak öneminin yeteri derece anlaşılmadığ 1 şeklinde yorumlanabilir.

Müstakil değerler başlığının ilk defa 2015 programıyla başladığı ve 2017, 2018 programlarında da devam ettiği görülmektedir. 2015 programında 20 değer, 2017 programında 22 değer yer alırken, 2018 programında ilk defa kök değer ifadesi ile 11 değer yer almaktadır. Ancak sayı azalmış gibi görünse de, Güven'in de (2013) belirttiği gibi Hayat bilgisi dersi öğretim programında "değerler" ifadesine doğrudan yer verilmezken, bazı değerlerin programda "kişisel nitelikler" başlığı altında yer aldığı görülmektedir. Kişisel nitelikler olarak özsaygı, öz güven, toplumsallık gibi değerler buna örnek olarak verilebilir. Ayrıca değer ifade eden kazanımların aynı zamanda beceriler başlığı altında da yer aldığı görülmektedir (Yaşaroğlu, 2013). Değerlerin müstakil bir başlık olarak programlarda yer alması, değerlere verilen önemin bir göstergesi olarak yorumlanabilir. Demir ve Demirhan İşcan (2007) 2005 hayat bilgisi programı üzerine yaptıkları bir araştırmada, programda yer almamasına rağmen ders kitaplarında ve öğrenci çalışma kitaplarında bazı değer ifadelerinin de yer aldığı sonucuna ulaşmışlardır.

Son olarak programların ölçme değerlendirmede dikkat edilmesi gereken hususlar belirtilirken, yine sadece 2015, 2017 ve 2108 programlarında değer vurgusu yapılmaktadır. Değerlerin amaçlanması, kazandırılmasında özen gösterilmesi gerektiği kadar, nasıl ölçülmesi gerektiği konusunda da öğretmenlere rehberlikte bulunulmalıdır. Yani değerlerin nasıl ölçülmesi gerektiği de önemli bir başlık olarak karşımıza çıkmaktadır. Özellikle son üç programda da bu vurgunun yapılmış olması, değer kazandırmaya daha bütüncül bir bakış açısının kabul edildiği şeklinde yorumlanabilir.

\section{Notlar}

${ }^{1} \mathrm{Bu}$ başlık altında yer alan bulguların bir kısmı, 05 - 08 Mayıs 2016 tarihleri arasında Çanakkale'de gerçekleşen VIII. Uluslararası Eğitim Araştırmaları Kongresi'nde sözlü bildiri olarak sunulmuştur.

\section{Kaynakça}

Adeyemi, M. B., Moumakwa, T. V., \& Adeyemi, D. A. (2009). Teaching character education across the curriculum and the role of stakeholders at the junior secondary level in Botswana. Studi Home Comm Sci, 3(2), 97-105.

Agboola, A., \& Tsai, K. C. (2012). Bring Character Education into Classroom. European journal of educational research, 1(2), 163-170.

Bacanlı, H. (1999). Duyuşsal davranış eğitimi. Ankara: Nobel.

Bacanlı, H. (2017). Değer bilinçlendirme yaklaşımı. İstanbul: Çizgi Kitapevi.

Bahçe, A. (2010). Hayat bilgisi öğretiminde dĕgerlerin kazandırılma düzeylerinin öğretmen görüşlerine göre değerlendirilmesi. Yüksek Lisans Tezi. Konya: Selçuk Üniversitesi.

Balc1, F. A., \& Yelken, T. Y. (2013). İlköğretim sosyal bilgiler programında yer alan değerler ve değer eğitimi uygulamaları konusunda öğretmen görüşleri. Ahi Evran Üniversitesi Kırşehir Eğitim Fakültesi Dergisi, 14(1), 195-213.

Burton, L. H. (1998). An Explicit or Implicit Curriculum: Which Is Better for Young Children?. 22nd World Congress of the Organisation Mondiale Pour l'Education Prescholarie, Copenhagen.

Curriculum Development Council (2001). Learning to learn: The way forward in curriculum development. Hong Kong: Hong Kong SAR Government.

Çekin, A. (2012). Değer açısından ilköğretim din kültürü ve ahlak bilgisi dersi kazanımları: Bir içerik analizi. Dinbilimleri Akademik Araştırma Dergisi, 12(2), 105119.

Demir, K., \& Demirhan İşcan, C. (2007). Hayat Bilgisi Dersinde Değerler ve Değerler Eğitimi. 1. Ulusal İlköğretim Kongresi. 15-17 Kasım 2007, Hacettepe Üniversitesi, Ankara.

DeNobile, J., \& Hogan, E. (2014). Values education: what, how, why and what next?. Curriculum \& Leadership Journal, 12(1).

Ekşi, H. (2004). Temel insani değerlerin kazandırılmasında bir yaklaşım: Karakter eğitimi programları. Değerler Eğitimi Dergisi, 1(1), 79-96.

Flay, B. R., \& Allred, C. G. (2010). The Positive Action Program: Improving academics, behavior, and character by teaching comprehensive skills for successful learning and living. Içinde: International research handbook on values education and student wellbeing, (ss. 471-501). Springer.

Gömleksiz, M. N., \& Cüro, E. (2011). Sosyal bilgiler dersi öğretim programında yer alan değerlere ilişkin öğrenci tutumlarının değerlendirilmesi. Uluslararası Insan Bilimleri Dergisi, 8(1), 95-134.

Güven, S. (2013). İlköğretim ders programlarının öğrenciye kazandırılması hedeflenen değerler açısından incelenmesi. Adlyaman Üniversitesi Sosyal Bilimler Enstitüsü Dergisi, 6(14), 355-374.

Inlay, L. (2003). Values: The Implicit Curriculum. Educational Leadership, 60(6), 69-71.

Jacobs, D. T., \& Jacobs-Spencer, J. (2001). Teaching virtues: Building character across the curriculum. Scarecrow Press.

Kabapınar, Y. (2007). 1998 ve 2004 öğretim programlarına göre yazılmış hayat bilgisi ve sosyal bilgiler ders kitaplarında sosyal olay ve değerlerin sunumu: işlev ve nitelik açısından farklı bir noktaya geldik mi?. Eğitim Bilimleri Dergisi, 25(25), 109-127.

Kaymakcan, R., \& Meydan, H. (2011). Din Kültürü ve Ahlak Bilgisi Programları ve Öğretmenlerine Göre Değerler Eğitimi. Dĕ̌gerler Ĕ̆itimi Dergisi, 9(21), 29-55. 
Keskin, S. C., \& Keskin, Y. (2009). Cumhuriyet dönemi ilkokul (ilköğretim 1. kademe) Sosyal Bilgiler ve onun kapsamına giren ders programlarında bir değer olarak "barış”1n yeri. Değerler Eğitimi Dergisi, 7(17), 69-92.

Keskin, Y. (2012). İlköğretim programlarındaki bazı ortak değerlerin kazanılma düzeylerinin bazı değişkenler açısından karşılaştırılması (Samsun ili örneği). The Journal of Academic Social Science Studies, 5(8), 827849. https://doi.org/10.9761/jasss_352

Kültür Bakanlığı (1937). Kültür Bakanlığı Dergisi Sayı 20-1 (Sonkanun). Ankara: Kültür Bakanlığı.

Lewis, S. V., Robinson, E. H., \& Hays, B. G. (2011). Implementing an Authentic Character Education Curriculum. Childhood Education, 87(4), 227-231. https://doi.org/10.1080/00094056.2011.10523183

Lickona, T. (1996). Teaching Respect and Responsibility. Reclaiming Children and Youth: Journal of Emotional and Behavioral Problems, 5(3), 143-151.

Lickona, T. (2004). Character Matters How to Help Our Children Develop Good Judgment, Integrity, and Other Essential Virtues. New York: Touchstone Books.

Lickona, T. (2009). Educating for character how our schools can teach respect and responsibility. New York: Bantam Books.

Lovat, T., Dally, K., Clement, N., \& Toomey, R. (2011). Values Pedagogy and Student Achievement: Contemporary Research Evidence. Netherlands: Springer. http://dx.doi.org/10.1007/978-94-007-1563-9

Maarif Vekâleti (1926). Ilk Mekteplerin Müfredat Programı. Milli Matbaa.

MEB (1948). İlk okul programı. İstanbul: Milli Eğitim Basımevi.

MEB (1968). İlk okul programı. İstanbul: Milli Eğitim Basımevi.

MEB (2002). Ilköğretim okulları ders programı (1. sınıf). İstanbul: Milli Eğitim Basımevi.

MEB (2009). Ilköğretim 1, 2 ve 3. Sintflar hayat bilgisi dersi ögretim programı ve kılavuzu. Ankara: Milli Eğitim Basımevi.

MEB (2015). Ilkokul hayat bilgisi dersi öğretim programı (1, 2 ve 3. sinıflar). Ankara: Milli Eğitim Basımevi.

MEB (2017). Illkokul hayat bilgisi dersi öğretim programı (1, 2 ve 3. sinıflar). Ankara: Milli Eğitim Basımevi.

MEB. (2018). Hayat Bilgisi dersi ögretim programı (ilkokul 1, 2 ve 3. sinıflar). Ankara: Milli Eğitim Basımevi.

Milson, A. J. (2000). Creating a Curriculum for Character Development: A Case Study. The Clearing House: A Journal of Educational Strategies, Issues and Ideas, 74(2), 89-93. https://doi.org/10.1080/00098655.2000.11478650

Narin, D. (2007). Illköğretim hayat bilgisi dersi öğretim programının vatandaşlık bilgi, beceri ve değerlerini kazandırmasına ilişkin ögretmen görüşleri. Yüksek Lisans Tezi. Eskişehir: Anadolu Üniversitesi.
Orhan, A. (2013). Hayat bilgisi dersi programının karakter ĕgitimi açısından öğretmen ve ögrenci perspektiflerine göre değerlendirilmesi. Yüksek Lisans Tezi. Sivas: Cumhuriyet Üniversitesi.

Öztürk, E. (2009). Hayat Bilgisi Dersinde Değer Eğitimi ve Örnek Uygulamalar. İçinde: İlköğretim Hayat Bilgisi Öğretimi ve Öğretmen El Kitabı, (Ed.) S. Öğülmüş. 479535.

Powney, J., Cullen, M.-A., Schlapp, U., Glissov, P., Johnstone, M., \& Munn, P. (1995). Understanding values education in the primary school. Edinburgh: Scottish Council for Research in Education.

Şimşek, N. (2013). Hayat bilgisinde kişisel nitelik(değer) öğretimi. The Journal of Academic Social Science Studies, 1(6), 1325-1346. https://doi.org/10.9761/jasss_511

TTKB (2018). Ilkokul Hayat Bilgisi Dersi (1, 2 ve 3. Sinıflar) Ögretim Programı. 19.01.2108 Tarih ve 13 Sayılı Kararı. Ankara: MEB Yayınları.

Türe, E. (2013). 1936 ilkokul programı. İçinde: Gözütok, F. D. ve B1kmaz, F. (Ed.). Cumhuriyet'in ilanından 2013'e ögretim programlarının analizi hayat bilgisi örneği (s.73-100). Ankara: Yarg1 Yayınevi.

UNESCO. (1992). Education for Affective Development: A Guidebook on Programmes and Practices. Thailand: UNESCO.

Uzunkol, E. (2014). Hayat bilgisi ögrretiminde uygulanan değerler ĕgitimi programının öğrencilerin özsayg düzeyleri, sosyal problem çözme becerileri ve empati düzeylerine etkisi (Basılmamış Yüksek Lisans Tezi). Gazi Üniversitesi, Eğitim Bilimler Enstitüsü, Ankara.

Yaşaroğlu, C. (2013). Hayat Bilgisi Dersi Kazanımlarının Değerler Eğitimi Açısından İncelenmesi. Journal of

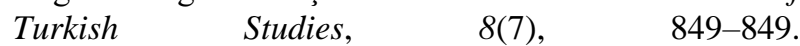
https://doi.org/10.7827/TurkishStudies.4838

Yaşaroğlu, C. (2015a). İlkokul programlarında yer alan değerler üzerine karşılaştırmalı bir inceleme. Route Educational and Social Science Journal, 2(7), 164-164. https://doi.org/10.17121/ressjournal.429

Yaşaroğlu, C. (2015b). Teachers' Opinions on Teaching and Assessing Methods in the Life Science Curriculum in the Context of Values. European Journal of Social Sciences Education and Research, 3(2), 107-112.

Yıldırım, A., \& Şimşek, H. (2016). Sosyal Bilimlerde Nitel Araştırma Yöntemleri. Ankara: Seçkin Yayıncılık. 